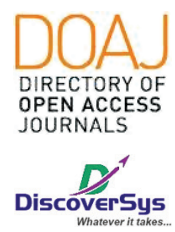

Published by DiscoverSys

\title{
Overview of adherence and factors related to medication adherence in hypertensive patients at Puskesmas Tembuku 1 Bali-Indonesia 2017
}

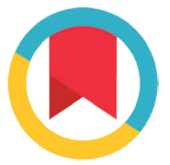

CrossMark

\author{
Thivyaroobini Ramah, ${ }^{1}$ Komang Ayu Kartika Sari ${ }^{2}$
}

\section{ABSTRACT}

Background: Hypertension remains a public health issue in Indonesia as its prevalence increases considerably. Adherence to treatment is an importantfactor in the long-term health and well-being of hypertensive patients. Basic Health Research (Riskesdas) in 2007 reported that the prevalence of hypertension in the population aged over 18 years in Indonesia is as high as $31.7 \%$, of which only $7.2 \%$ known that they had hypertension and only $0.4 \%$ took antihypertensive medications. Coverage of hypertension cases at Puskesmas Tembuku I in 2016 increased by 50\% from the previous year, from 292 cases to 584 cases. Methods: The research was conducted in the coverage area of Tembuku I Community Health Center, Bangli Regency, in 2017. The descriptive cross-sectional method was used in this research. 81 respondents were chosen as research sample using non-probability consecutive sampling method. Primary data were collected through interviews on the research sample using questionnaire and Morisky Medication Adherence Scale (MMAS-8).

Results: Most of the respondents had low medication adherence (96.3\%), followed by moderate adherence (3.7\%). None of the respondents had high medication adherence. Most of the respondents had low knowledge of hypertension (70.4\%) and had sufficient access to healthcare facilities (71.6\%). Most of the respondents reported high family support (93.8\%), and high support from healthcare officials (71.6\%). Most of the respondents (97.5\%) reported high motivation.

Conclusion: Low medication adherence and low knowledge regarding hypertension were observed, despite sufficient access to healthcare facilities, high family and healthcare officials support, and high motivation in hypertensive patients.

Keywords: Hypertension, Medication Adherence

Cite This Article: Ramah, T., Sari, K.A.K. 2018. Overview of adherence and factors related to medication adherence in hypertensive patients at Puskesmas Tembuku 1 Bali-Indonesia 2017. Intisari Sains Medis 9(1): 37-42. D0I: 10.1556/ism.v9i1.153

ABSTRAK

Latar Belakang: Hipertensi masih menjadi salah satu masalah kesehatan masyarakat di Indonesia, seiring dengan prevalensinya yang terus meningkat. Kepatuhan terhadap pengobatan merupakan faktor yang penting dalam kesehatan dan kesejahteraan jangka panjang pada pasien hipertensi. Riset Kesehatan Dasar (Riskesdas) pada tahun 2007 menunjukkan bahwa prevalensi hipertensi pada penduduk berusia di atas 18 tahun di Indonesia mencapai 31,7\%, dimana hanya $7,2 \%$ mengetahui bahwa dirinya menderita hipertensi, dan hanya 0,4\% mengkonsumsi obat antihipertensi. Cakupan kasus hipertensi di Puskesmas Tembuku I pada tahun 2016 meningkat sebesar 50\% dibanding tahun sebelumnya, dari 292 menjadi 584 kasus.

Metode: Penelitian ini dilaksanakan di wilayah kerja Puskesmas Tembuku I, Kabupaten Bangli, pada tahun 2017. Metode deskriptif potong lintang digunakan dalam penelitian ini. Dengan menggunakan metode sampling konsekutif, 81 orang responden terpilih sebagai sampel penelitian. Data primer dikumpulkan melalui wawancara pada respoden menggunakan kuesioner dan Morisky Medication Adherence Scale (MMAS-8)

Hasil: Sebagian besar responden memiliki kepatuhan pengobatan yang rendah (96,3\%), diikuti kepatuhan sedang (3,7\%). Tidak ada responden yang menunjukkan kepatuhan pengobatan tinggi. Sebagai besar responden $(70,4 \%)$ memiliki pengetahuan yang rendah mengenai hipertensi, dan memiliki akses layanan kesehatan yang baik (71,6\%). Sebagian besar responden mendapat dukungan yang baik dari keluarga (93,8\%), dan dari petugas kesehatan $(71,6 \%)$. Sebagian besar responden $(97,5 \%)$ memiliki motivasi yang tinggi.

Simpulan: Didapatkan kepatuhan pengobatan dan pengetahuan mengenai hipertensi yang rendah pada pasien, walaupun terdapat akses layanan kesehatan yang baik, dukungan yang tinggi dari keluarga dan petugas kesehatan, dan motivasi yang tinggi.
*Correspondence to: rubzzsagi@gmail.com

Received: 2018-01-18 Accepted: 2018-01-23 Published: 2018-01-27
Kata Kunci: Hipertensi, Kepatuhan pengobatan

Cite Pasal Ini: Ramah, T., Sari, K.A.K. 2018. Overview of adherence and factors related to medication adherence in hypertensive patients at Puskesmas Tembuku 1 Bali-Indonesia 2017. Intisari Sains Medis 9(1): 37-42. D0I: 10.1556/ism.v9i1.153 


\section{INTRODUCTION}

Hypertension remains a global public health issue. Besides its high prevalence and increasing incidence, hypertension is one of the most common causes of death. Hypertension was considered as a "silent killer" due to its asymptomatic nature. Most of the hypertensive patients did not know that they suffered from hypertension, and it usually diagnosed incidentally by clinician while examining for other complaints. ${ }^{1}$ Hypertension is one the main risk factor of cardiovascular disease, stroke, and other complications. ${ }^{2}$

According to the World Health Organization (2013), one billion people suffered from hypertension worldwide and two-thirds of them in low to middle-income developing countries. ${ }^{1}$ In 2012, statistically, one in three adults in every country in the world are hypertensive. ${ }^{3}$ The incidence of hypertension tend to increase every year, from 600 million people in 1980 to 1 billion in 2008. ${ }^{1}$

In Indonesia, based on Riskesdas 2013, the national prevalence of hypertension was $25.8 \%$. With a total population of 252.124 .458 people, there are approximately 65.048 .110 people with hypertension in Indonesia. These findings suggest that the prevalence of hypertension in Indonesia remains high. The prevalence of hypertension in adults aged over 18 years diagnosed by health officials was $9.4 \%$, while the prevalence based on direct blood pressure measurement was $25.8 \%$. In Bali, the prevalence of hypertension in adults aged over 18 years based on direct blood pressure measurement was $20 \%$; meanwhile, based on health official diagnosis, the prevalence was $9 \%$.

Tembuku I Community Health Center (PUSKESMAS Tembuku I) is one of several community health centers in Bangli regency. Based on the clinical register from January to December 2016, hypertension was one of the ten most common diseases in the coverage area of PUSKESMAS Tembuku I. Hypertension was ranked as the 5th most common disease with 584 clinical visits. However, these visits only include symptomatic patients who came to the community health center. The clinical visit in 2016 increases considerably from the previous year, in which there are only 292 cases of hypertension. Hypertension tended to be asymptomatic and progressed as a "silent killer," therefore some hypertensive patients may not know that they had hypertension since they had no complaints and did not visit the community health center. It made the actual prevalence of hypertension in the coverage area of Puskesmas Tembuku I difficult to determine.
One of the risk factors for increased morbidity and mortality caused by hypertension is bad adherence to hypertensive medications prescribed by the clinician. Adherence to therapy is an important issue in the management of chronic diseases; therefore, evaluation of patient adherence is necessary to ensure effective management.

Adherence to therapy is an important factor in the long-term health and wellbeing of hypertensive patients. Adherence to therapy is a prerequisite for effective management of hypertension, and changing the behavior of hypertensive patient regarding adherence had the potential to improve control of hypertension. Bad adherence to hypertensive medications was one of the main cause of failure in the management of hypertension. ${ }^{4,5}$ A study in Nigeria also shown that from 357 hypertensive patients, $66.7 \%$ of patients had bad adherence to hypertensive medications; in which patient education level and access to healthcare facilities were shown to be correlated with adherence to therapy. ${ }^{6}$

Therefore, an exploratory study is needed to investigate medication adherence and factors affecting adherence in hypertensive patients in the coverage area of PUSKESMAS Tembuku I. The data gained by this study may assist in designing health policy and health promotion program in managing hypertension.

\section{METHODS}

The study was conducted in four villages in the area covered by PUSKESMAS Tembuku I in November 2017. The descriptive cross-sectional method was used in this study. Using consecutive non-probability sampling method from the patient register of PUSKESMAS Tembuku I between July to September 2017, 81 hypertensive patients who had received antihypertensive medication for a minimum of three months were included in the study.

Primary data were collected by interviews using Morisky Medication Adherence Scale (MMAS-8) and questionnaire based on the study by Puspita in $2016{ }^{7}$ Sample characteristics, including sex, education level, occupation status, duration of therapy, presence of side effects of the medications, knowledge regarding hypertension, access to healthcare facilities, family support, and support from health officials, patient motivation, and medication adherence were obtained during interviews.

Knowledge regarding hypertension was assessed using questionnaire consisting of 10 questions about hypertension. Respondents scoring $\geq 5$ were considered as having high knowledge regarding 
hypertension, and those scoring $<5$ were considered as having low knowledge.

Family and healthcare officials support were assessed using questionnaires by Azwar (2011) consisting of five questions. Respondents scoring $\geq 3$ were considered as having high support, and those scoring $<3$ were considered as having low support. $^{8}$

Respondent motivation was assessed using a questionnaire by Azwar (2011) consisting of eight

\section{Table 1 Characteristics of Respondent}

\begin{tabular}{|c|c|c|}
\hline Characteristics & Frequency & Percentage (\%) \\
\hline \multicolumn{3}{|l|}{ Sex } \\
\hline Male & 33 & 40.7 \\
\hline Female & 48 & 59.3 \\
\hline \multicolumn{3}{|l|}{ Education Level } \\
\hline Low & 76 & 93.8 \\
\hline High & 5 & 6.2 \\
\hline \multicolumn{3}{|l|}{ Occupation } \\
\hline Not working & 25 & 30.9 \\
\hline Working & 56 & 69.1 \\
\hline \multicolumn{3}{|c|}{ Duration of therapy } \\
\hline$<6$ months & 25 & 30.9 \\
\hline$>6$ months & 56 & 69.1 \\
\hline \multicolumn{3}{|l|}{ Side effects } \\
\hline Present & 70 & 86.4 \\
\hline None & 11 & 13.6 \\
\hline \multicolumn{3}{|l|}{ Adherence } \\
\hline Low & 78 & 96.3 \\
\hline Moderate & 3 & 3.7 \\
\hline \multicolumn{3}{|l|}{ Knowledge } \\
\hline Low & 57 & 70.4 \\
\hline High & 24 & 29.6 \\
\hline \multicolumn{3}{|c|}{ Access to healthcare facilities } \\
\hline Limited & 23 & 28.4 \\
\hline Sufficient & 58 & 71.6 \\
\hline \multicolumn{3}{|l|}{ Family support } \\
\hline Low & 5 & 6.2 \\
\hline High & 76 & 93.8 \\
\hline \multicolumn{3}{|c|}{ Healthcare officials support } \\
\hline Low & 23 & 28.4 \\
\hline High & 58 & 71.6 \\
\hline \multicolumn{3}{|l|}{ Motivation } \\
\hline High & 79 & 97.5 \\
\hline Low & 2 & 2.5 \\
\hline
\end{tabular}

questions. Respondents scoring $\geq 5$ were considered as having high motivation and those scoring $<5$ were considered as having low motivation. ${ }^{8}$

Medication adherence was assessed using a modified questionnaire by Morisky and Munter (2009). Respondents are scoring $<6$ were considered as having low adherence, those scoring 6-75 were considered as having moderate adherence, and those scoring 8 were considered as having high adherence. $^{9}$

Collected data were analyzed accordingly using descriptive statistics.

\section{RESULTS}

The characteristics of respondent were shown in Table 1. Most of the respondents were female (59.3\%), had a low educational level (93.8\%), and currently still working (69.1\%). Most of the respondents were treated for hypertension for $>6$ months (69.1\%), and side effects were reported in $13 \%$ respondents. Regarding knowledge, most of the respondents $(70.4 \%)$ had low knowledge of hypertension. Low medication adherence was found in 74 (97.4\%) of 76 respondents with low educational level, and two respondents (2.6\%) had moderate adherence.

Table 2 showed the result of cross-tabulation between characteristics of respondent and medication adherence. Meanwhile, in the high knowledge group, 22 (91.7\%) out of 24 respondents had low medication adherence, and two (8.3\%) had moderate adherence. In the group with limited access to healthcare facilities, 22 (97.7\%) out of 23 respondents had low medication adherence, and one (4.3\%) had moderate adherence. Out of 58 respondents with sufficient access to healthcare facilities, 56 (96.6\%) had low medication adherence, and two $(3.4 \%)$ had moderate adherence. All five of respondents who reported low family support had low medication adherence. Out of 76 respondents with good family support, 73 (90.2\%) had low adherence, and three (5.2\%) had moderate adherence. All 23 respondents who reported low healthcare officials support had low medication adherence. Meanwhile, 55 (94.8\%) of 58 respondents with good support from healthcare officials had low medication adherence, and three (3.7\%) had moderate adherence. Out of 79 respondents with low motivation, 77 (97.5\%) had low medication adherence, and two (2.5\%) had moderate adherence. Meanwhile, one (50\%) of two respondents reported high motivation had low medication adherence, and one (50\%) had moderate adherence. 
Table 2 Characteristics of Respondent and Medication Adherence

\begin{tabular}{|c|c|c|c|c|c|c|}
\hline \multirow[b]{3}{*}{ Characteristics } & \multicolumn{4}{|c|}{ Medication Adherence } & & \\
\hline & \multicolumn{2}{|c|}{ Low } & \multicolumn{2}{|c|}{ Moderate } & \multicolumn{2}{|c|}{ Total } \\
\hline & $f$ & $\%$ & $\mathbf{f}$ & $\%$ & $f$ & $\%$ \\
\hline \multicolumn{7}{|l|}{ Sex } \\
\hline Male & 31 & 93.9 & 2 & 6.1 & 33 & 100 \\
\hline Female & 47 & 97.9 & 1 & 2.1 & 48 & 100 \\
\hline \multicolumn{7}{|l|}{ Education Level } \\
\hline Low & 74 & 97.4 & 2 & 2.6 & 76 & 100 \\
\hline High & 4 & 80 & 1 & 20 & 5 & 100 \\
\hline \multicolumn{7}{|l|}{ Occupation } \\
\hline Not working & 25 & 100 & 0 & 0 & 25 & 100 \\
\hline Working & 53 & 94.6 & 3 & 5.4 & 56 & 100 \\
\hline \multicolumn{7}{|c|}{ Duration of therapy } \\
\hline$<6$ months & 22 & 88 & 3 & 12 & 25 & 100 \\
\hline$>6$ months & 56 & 100 & 0 & 0 & 56 & 100 \\
\hline \multicolumn{7}{|l|}{ Side effects } \\
\hline Present & 10 & 90.9 & 1 & 9.1 & 11 & 100 \\
\hline None & 68 & 97.1 & 2 & 2.9 & 70 & 100 \\
\hline \multicolumn{7}{|l|}{ Knowledge } \\
\hline Low & 56 & 98.2 & 1 & 1.8 & 57 & 100 \\
\hline High & 22 & 91.7 & 2 & 8.3 & 24 & 100 \\
\hline \multicolumn{7}{|c|}{ Access to healthcare facilities } \\
\hline Limited & 22 & 95.7 & 1 & 4.3 & 23 & 100 \\
\hline Sufficient & 56 & 96.6 & 2 & 3.4 & 58 & 100 \\
\hline \multicolumn{7}{|l|}{ Family support } \\
\hline Low & 5 & 100 & 0 & 0 & 5 & 100 \\
\hline High & 73 & 96.0 & 3 & 4.0 & 76 & 100 \\
\hline \multicolumn{7}{|c|}{ Healthcare officials support } \\
\hline Low & 23 & 100 & 0 & 0 & 23 & 100 \\
\hline High & 55 & 94.8 & 3 & 5.2 & 58 & 100 \\
\hline \multicolumn{7}{|l|}{ Motivation } \\
\hline High & 77 & 97.5 & 2 & 2.5 & 79 & 100 \\
\hline Low & 1 & 50 & 1 & 50 & 2 & 100 \\
\hline
\end{tabular}

\section{DISCUSSION}

Results from this study showed that female with hypertension had a higher proportion of low medication adherence $(97.9 \%)$, compared to male hypertensives (93.9\%). These findings indicate that females tend to have lower adherence compared to male. Nevertheless, gender difference could not be used to determine adherence, since previous studies shown mixed results. Another study by Hazwan and Pinatih (2017) shown that out of 28 female respondents, $5(17.9 \%)$ had high medication adherence, and $23(82.1 \%)$ had low adherence. ${ }^{5}$
Education level is an important factor in determining medication adherence. This study showed that respondents with low education level had a higher proportion of low medication adherence (97.4\%) compared to respondents with high education level (80\%). This study result was similar to a study by Boima et al. (2015), which shown that $85 \%$ of hypertensives with high education level had high medication adherence. ${ }^{6}$

According to Lawrence Green (1980), human behavior was affected by several predisposing factors, including education. Education was defined as an activity or process of learning to develop or intensify a particular skill so that it can be done independently. ${ }^{10}$ Respondents with higher education tend to show a wider range of knowledge compared to respondents with low education level. Sugiharto et al. (2007) shown that education level affects the knowledge and ability to conduct healthy lifestyle, specifically in preventing hypertension. ${ }^{11}$ Higher education level correlated with higher ability in maintaining a healthy lifestyle.

Education is closely related to knowledge. Education is a process of learning to achieve a particular set of behavior or activity. By learning, both formally and informally, human develop their intellectual maturity and gather a wider range of knowledge. Hypertensive patients with a wider range of knowledge will achieve a better understanding of healthcare official's suggestion. Therefore they are more likely to have higher medication adherence.

Respondent's occupation may also affect medication adherence. This study showed all 25 respondents who were not working and $94.6 \%$ of those who were working had low medication adherence. This result indicates that respondents who are working tend to have low medication adherence, probably due to limited time in taking medications. These findings are similar to a study by Hazwan and Pinatih (2017), which showed that out of 21 non-working respondents, eight respondents (38.1\%) had high medication adherence, and $13(61.9 \%)$ had low adherence. Meanwhile, in 29 working respondents, seven $(24.1 \%)$ had high medication adherence, and $22(75.9 \%)$ had low adherence. $^{5}$

This study showed that respondents who took hypertensive medication for $>6$ months had a higher proportion of low medication adherence (100\%) compared to those taking antihypertensive medication for $<6$ months. This study result indicates that longer duration of therapy may worsen medication adherence, probably caused by little or no effect of the medications was felt by the respondents, even over a long period. Therefore, the 
respondents may have felt weary of taking the same medication every day.

This study showed that respondents who experienced side effects had a lower proportion of low medication adherence $(90.9 \%)$ compared to those who reported no side effects (97.1\%). These findings contradict a study by Dusing et al. in Germany (1998) in which medication side effects were the most common cause of low medication adherence in hypertensive patients. ${ }^{12}$

Knowledge may also affect medication adherence. This study showed that respondents with low knowledge of hypertension had a higher proportion of low medication adherence (98.2\%) compared to those with more knowledge regarding hypertension (91.7\%). These findings indicate that patients without sufficient knowledge regarding hypertension tend to have lower medication adherence. These findings are by the theory by Lawrence Green, which stated that knowledge is one of the predisposing factors in human behavior. ${ }^{10}$

Another study by Puspita (2016) also shown that respondents with lower knowledge of hypertension tend to have lower medication adherence. (7) These findings may be caused by higher understanding in patients with sufficient knowledge of hypertension regarding their treatment, and the risk of uncontrolled hypertension. Therefore, they adhere to the treatment and suggestion of healthcare officials. Medication adherence in patients with higher knowledge of hypertension may also be related to their motivation since $81 \%$ of respondents with sufficient knowledge of hypertension also had high motivation.

Access to healthcare facilities may affect medication adherence. This study showed that respondents with limited access to healthcare facilities had similar adherence to those with sufficient access, $95.7 \%$, and $96.6 \%$ respectively. These findings indicate that access to healthcare facilities is not a driver of medication adherence. These findings were in accordance with a study by Anissa (2013), which stated that access to healthcare facilities was defined as the degree of difficulty faced by the patients in order to reach healthcare facilities. ${ }^{4}$ Niven (2002) stated that one of the factors affecting medication adherence is enabling factors, including the availability of healthcare facilities, access to healthcare facilities, and socioeconomic and cultural factors. Low utilization of healthcare facilities, including PUSKESMAS and hospital, was usually attributed to the access to healthcare facilities. Access to healthcare facilities was defined regarding distance, duration of travel, and availability of transportation to the healthcare facilities. Longer distance and difficult transportation to healthcare facilities will affect medication adherence. ${ }^{13}$
This study showed that even in respondents with high family support, the proportion of low medication adherence was $94.8 \%$. These indicate that family support alone may not be enough to increase medication adherence. It may be caused by low motivation, educational level, and knowledge regarding hypertension in the patients. A theory of family support by Friedman (2002) stated that family support is attitudes, actions, and acceptance of the patients by their family. ${ }^{14}$ Family support is needed by the patients since they need close attention. The family may act as motivators toward the patient to keep a positive attitude of the patients regarding their illness, therefore adhere to the treatment recommended by healthcare officials. In reality, high family support was not enough to drive high medication adherence; this may be caused by respondent's occupation, which is mainly in agriculture and trade, therefore limiting their time to interact and discuss their illness to their family.

Healthcare officials are supporting factors in increasing adherence. This study showed that even in respondents who reported high support by healthcare officials, the proportion of low medication adherence was still $94.8 \%$. These findings indicate that the role of healthcare officials in increasing medication adherence is still limited. It may be affected by the low transfer of information and limited understanding of suggestion and explanations by healthcare officials. According to the theory by Lawrence Green (1980), the reinforcing factors of behavior includes supportive attitude and actions of healthcare officials toward the patient. ${ }^{10}$ In reality, however, patients often prefer alternative medicine including herbs in treating their illness. Therefore they rarely visit healthcare facilities even if it was accessible. Economic factors may also play a role in the utilization of healthcare facilities; therefore even if healthcare officials play an important role in giving care and information, it was not effective in increasing medication adherence.

This study showed that respondents with low motivation had a higher proportion of low medication adherence (97.5\%), compared to those with high motivation (50\%). These findings were by the study by Rajasati (2015) who studied factors affecting medication adherence in hypertensive patients in Semarang, in which chi-square statistics test shown that motivation was correlated with medication adherence. $^{15}$

\section{CONCLUSION}

Most of the respondents had low medication adherence (96.3\%), followed by moderate adherence $(3.7 \%)$. None of the respondents had high medication adherence. 
Most of the respondents had low knowledge of hypertension (70.4\%) and had sufficient access to healthcare facilities (71.6\%). Most of the respondents reported high family support $(93.8 \%)$, and high support from healthcare officials (71.6\%). Most of the respondents (97.5\%) reported high motivation.

\section{REFERENCES}

1. World Health Organization. Adherence to Long Term Therapies: Evidence for Action Geneva: World Health Organization; 2003.

2. IFPMA. Hypertension: Putting the Pressure on The Silent Killer Geneva: IFPMA; 2016.

3. Balitbang Kemenkes RI. Riset Kesehatan Dasar 2013 Jakarta: Kementrian Kesehatan RI; 2013.

4. Anissa AFN. Faktor yang Berhubungan dengan Kepatuhan Berobat Hipertensi pada Lansia di Puskesmas Pattingallong Kota Makasar. Ejournal Universitas Hassanudin. 2013.

5. Hazwan A, Pinatih G. Gambaran karekteristik penderita hipertensi dan tingkat kepatuhan minum obat di wilayah kerja Puskesmas Kintamani I. Intisari Sains Medis. 2017; 8(2): p. 130-134.

6. Boima V, Ademola AD, Odusola AO, Agyekum F, Nwafor CE, Cole $\mathrm{H}$, et al. Factors Associated with Medication Nonadherence Among Hypertensives in Ghana and Nigeria. International Journal of Hypertension. 2015.
7. Puspita E. Faktor-faktor yang berhubungan dengan kepatuhan penderita hipertensi dalam menjalani pengobatan. Ejournal Universitas Negeri Semarang. 2016.

8. Azwar S. Perhitungan Sampel dan Skala Psikologi Jakarta: Salemba Medika; 2011.

9. Morisky D, Munter P. New Medication Adherence Scale Versus Pharmacy Fill Rates in Seniors With Hypertension. American Journal of Managed Care. 2009; 15(1): p. 59-66.

10. Notoatmodjo S. Metodologi Penelitian Kesehatan Jakarta: Rineka Cipta; 2010.

11. Sugiharto A. Faktor-faktor RIsiko Hipertensi Grade II Pada Masyarakat (Studi Kasus di Kabupaten Karanganyar). Ejournal UNDIP. 2007.

12. Dusing R, Weisser B, Mengden T. Changes in antihypertensive therapy-the role of adverse effects and compliance. Blood Press. 1998; 7: p. 313-315.

13. Niven N. Psikologi Kesehatan Keperawatan: Pengantar Untuk Perawat dan Professional Kesehatan Lain Jakarta: EGC; 2002.

14. Friedman, Marilyn M. Buku Ajar Keperawatan Keluarga Jakarta: EGC; 2010.

15. Rasajati QP, Raharjo BB, Ningrum DNA. Faktor-faktor yang Berhubungan Dengan Kepatuhan Pengobatan pada Penderita Hipertensi di Wilayah Kerja PUSKESMAS Kedungmundu Kota Semarang. EJournal UNNES. 2015; 3.

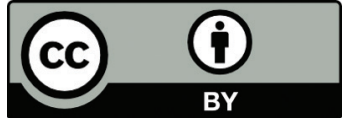

This work is licensed under a Creative Commons Attribution 